تحليل دقت روشهاى بهنهبندى بارش بر پايه تكنيكهاى درونيابى

مكانى در حوضه آبريز زايندهرود

محمدامين امينى '، غزاله تر كان'، سيد سعيد اسلاميان'، محمدجواد زارعيانَّ و على اصغر بسالتيورّ

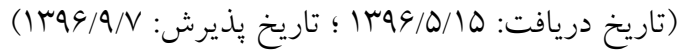

جكيده

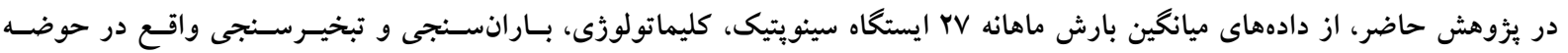

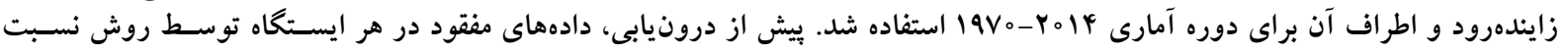

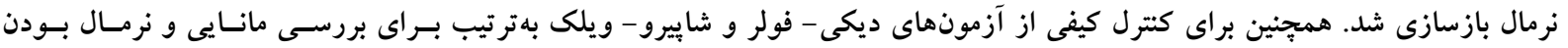

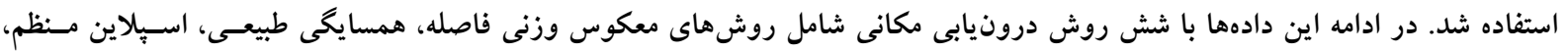

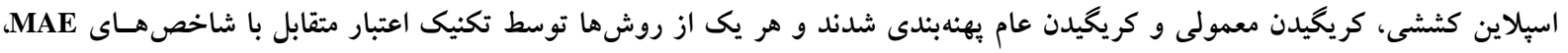

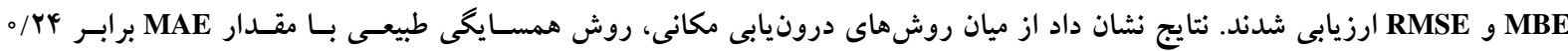

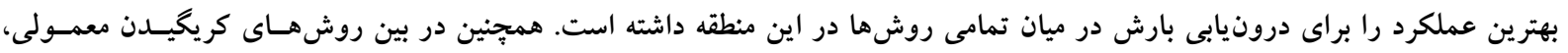

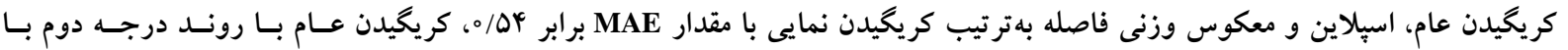

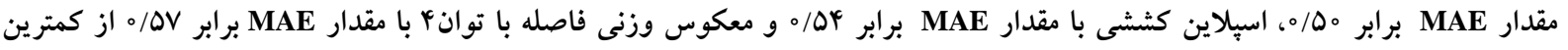

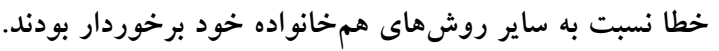

وازههاى كليدى: آزمون ديكى - فولر، آزمون شايِيرو- ويلك، بارش ماهانه، حوضه آبريز زايندهرود، روشهاى درونيابى مكانى

\footnotetext{
ا. گروه مهندسى آب، دانشكده كشاورزى، دانشخاه صنعتى اصفهان r. مؤسسه تحقيقات آب، وزارت نيرو، تهران، ايران

r. مؤسسه مديريت منابع Inter r GmbH، برلين، آلمان
}

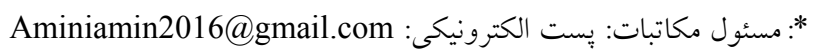


و الزهرانى روش كوكريخيدن را نسبت به روشهـاى كريخيـدن مقدمه

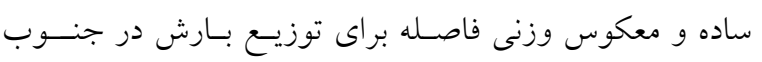

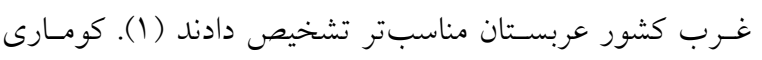

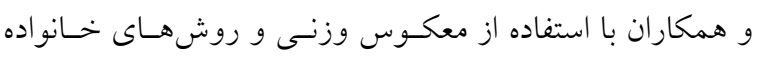

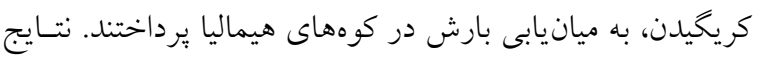

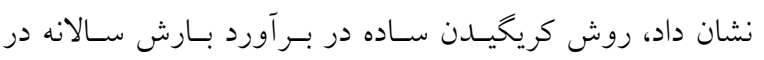

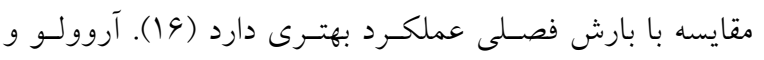

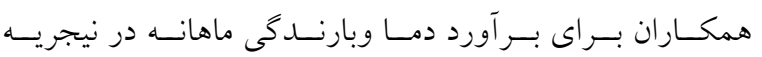
از روشهاى كريخيدن رونددار و اسيلاين استفاده كردند، نتسايج نشانداد در منطقه مـورد مطالعـه روشهـــاى خـانو اده اسـيلاين

نسبت به روش كريخيدن رونددار مناسبتر هستند (Y).

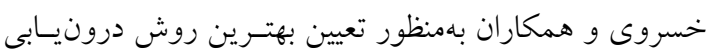

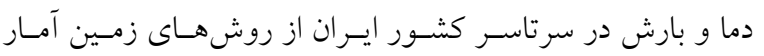

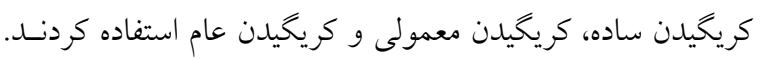
نتايج نشان داد كه روش كريخيدن ساده از نوع نمايى و كريخيـدن معمولى از نوع كروى بهترين روش براى درونيابى بـارش و دمهـا

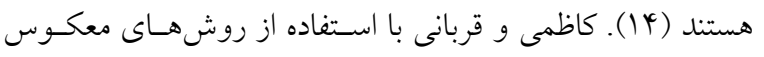

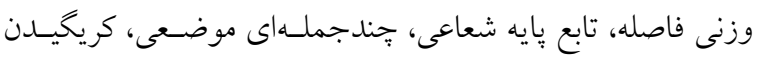

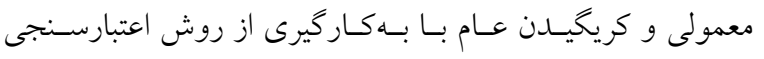

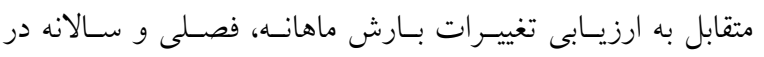

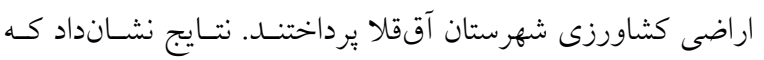

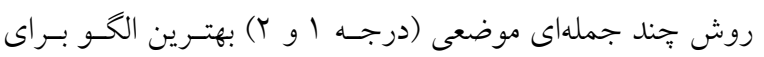
تخمين تمامى متغيرهاى بارش به جز بارش بهـاره و خهـرداد مـاه

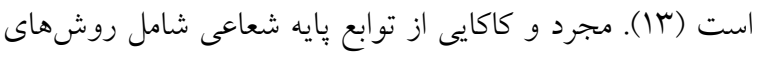

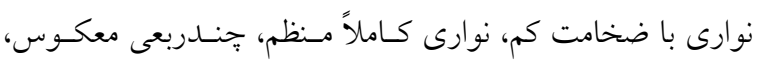

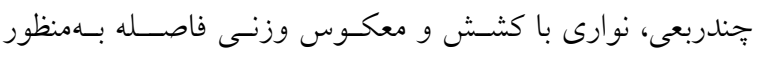

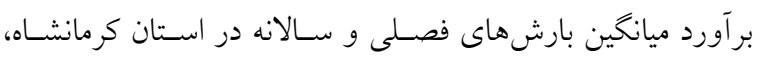

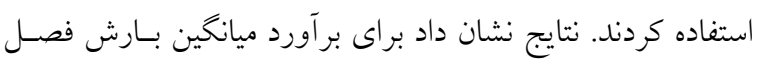

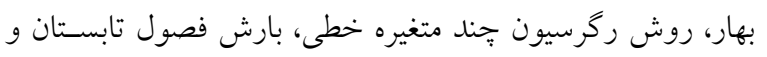

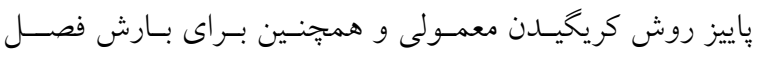

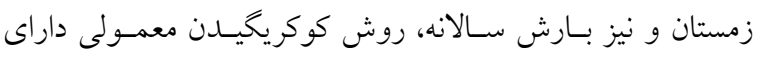

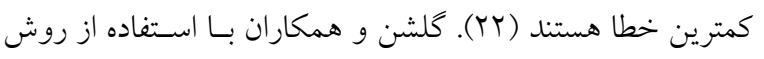
بارش از جمله متغيرهاى اقليمى بيوسته است كه نقشى اساسى در

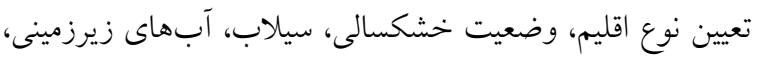

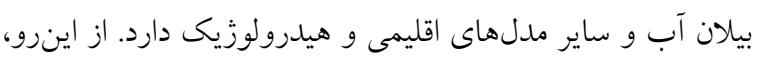

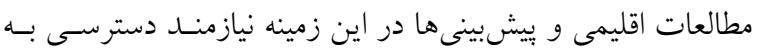

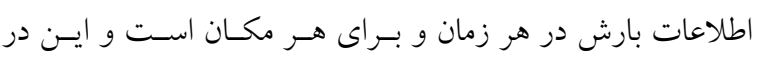

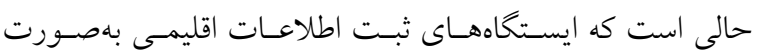

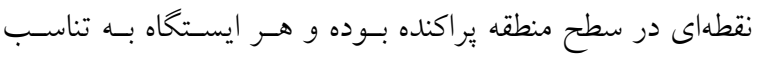

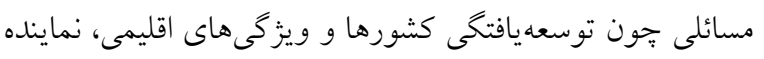
منطقهاى در اطر اف خود است. همجنين تعميم اطلاعات اين نقاط توني

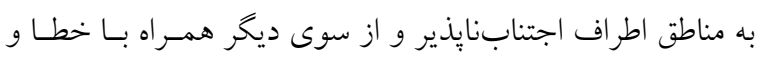

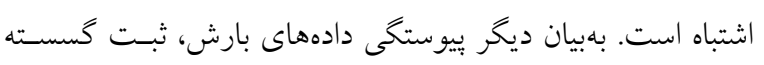

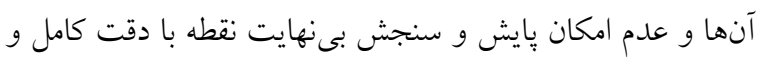

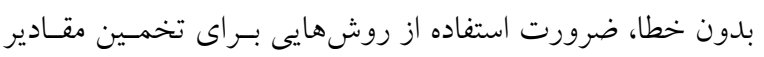

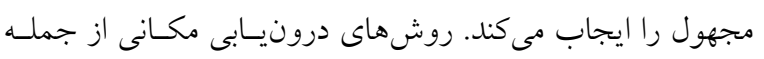
روشهايى است كه با بهكارگيرى از مدلهاى درونيـاب، از آنها

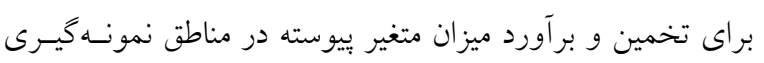

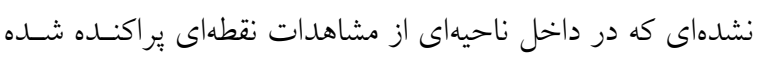

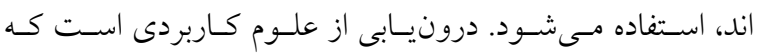

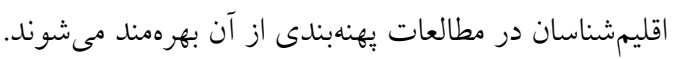

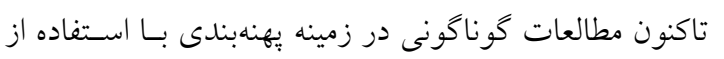
روشهاى درونيابى انجام شده است. مـورال نشـان داد كـهـ در

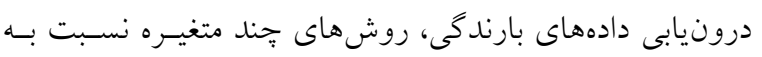

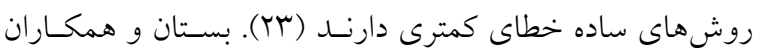

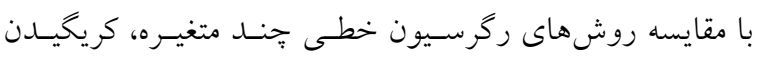

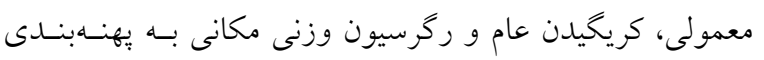

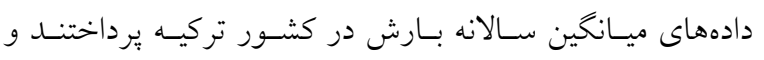
كزارش كردند كه كريخيدن عام با داشتن كمترين ريشه ميانخين

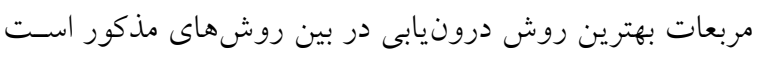

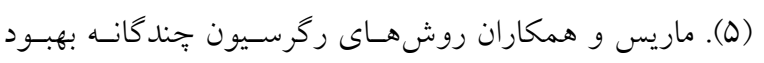

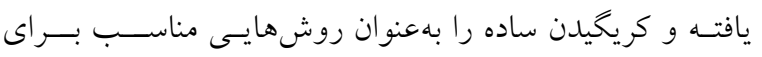
بـرآورد بـارش در كشور قبرس تشخيص دادند (19). ابومناصر 
خود جزئى از حوضه آبريـز كـوير مركـزى ايـران اسـت (بس).

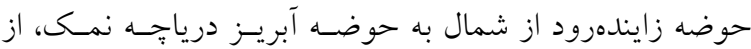

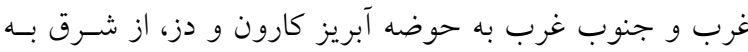

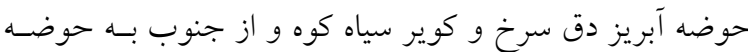

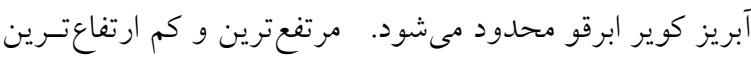

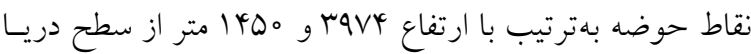

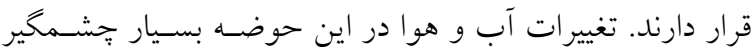

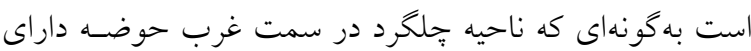

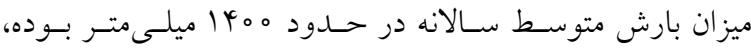
درحالى كه در شرق حوضه در محدوده تالاب كَاوخونى بـارش

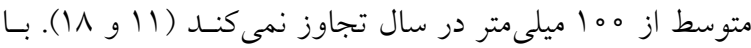

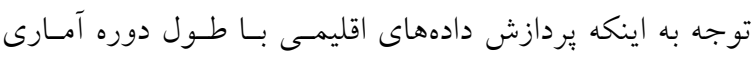
بيشتر نتايج بهتر و دقيقترى را نشان مى دهد، براى دسـيابى بـهـ

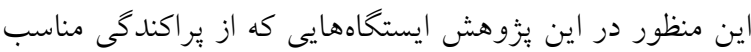

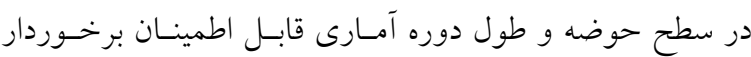

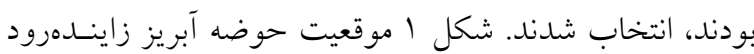

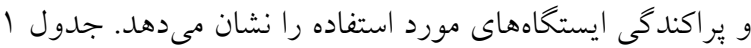
نيز مشخصات جغرافيايى و نوع ايستاههاى هواشناسى مـورد

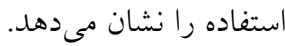
در اين يزوهش از اطلاعات ميانخين بارش ماهانه rV ايستخاه هو اشناسى تهيه شده از سازمان هواشناسى و سازمان آب منطقهاى

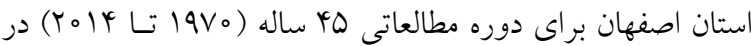
حوضه آبريز رودخانه زايندهرود استفاده شد.

\section{ي يش آزمونهاى آمارى}

با توجه به كامل نبودن آمار مربوط بـهـ برخسى از ايستخاههـا، از

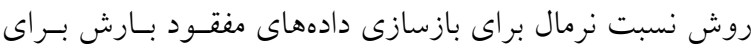
هر ايستخاه اقدام شد. نسبت نرمـال از روشهــاى متــداول آمـار كلاسيك براى بازسازى دادههاى مفقود است (YT). همجنين بـهـ منظور كنترل كيفى و تحليل مشخصات آمارى دادههـاى بـارش

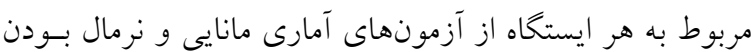
دادهها به كار گيرى شد.
هاى درونيابى قطعى شامل معكوس وزنى فاصـله، קֶندجملـهـاى

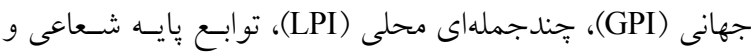

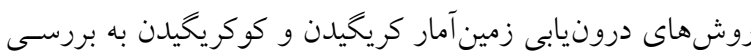

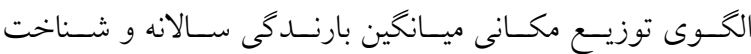
مناسبترين روش درونيابى در كستره كشـور ايسران يرداختنـــ. نتايج نشان داد روش تابع بايه شعاعى با مدل جندربعى نسبت بـهـ

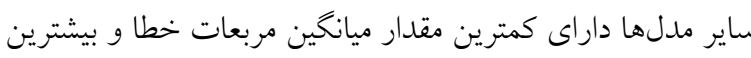

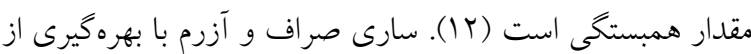

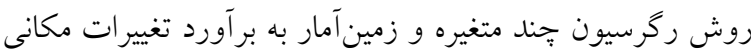
بارش در دامنههاى غربى زاكرس مركزى اقدام كردند. نتايج نشان

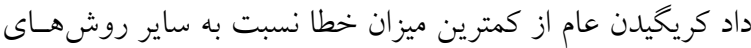

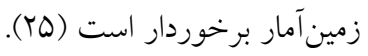

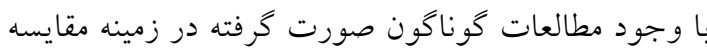
روشهاى درونيابى مكانى، به نظر مىرسد كه تاكنون مطالعسه

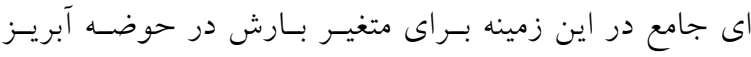

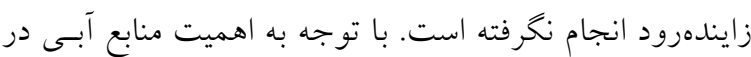
ايسن حوضـه، مطالعـه در زمينـهـ انتخــاب روشهــاى بهينـهـ درونيابى مكانى، امـرى ضـرورى بـهنظــ مسرســـ در ايسن يُزوهش سعى بر آن شده تا تغييـرات زمـانى و مكـانى بـارش

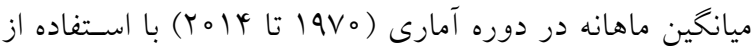
شش روش درونيابى مكانى در حوضه آبريز زايندهرود مسورد بررسى قرار گيرد. هدف اصلى در اين يزوهش مقايسـه روش

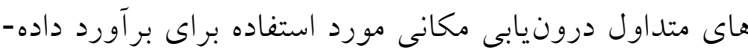

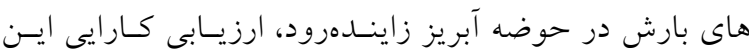
روشها و درنهايت تعيين بهترين روش درونيابى مكانى براى اين منطقه است.

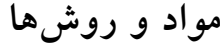

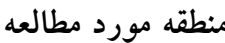

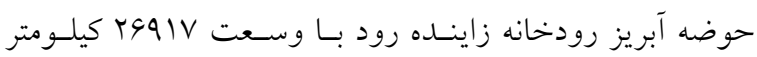

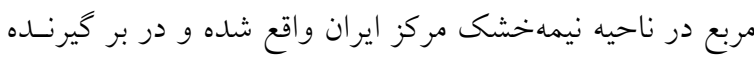

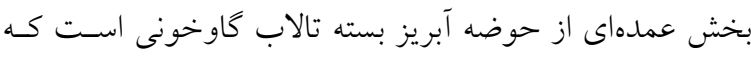


نشريه علوم آب و خاك (علوم و فنون كشاورزى و منابع طبيعى) / سال بيست و سه / شماره اول / بهار \هـ1

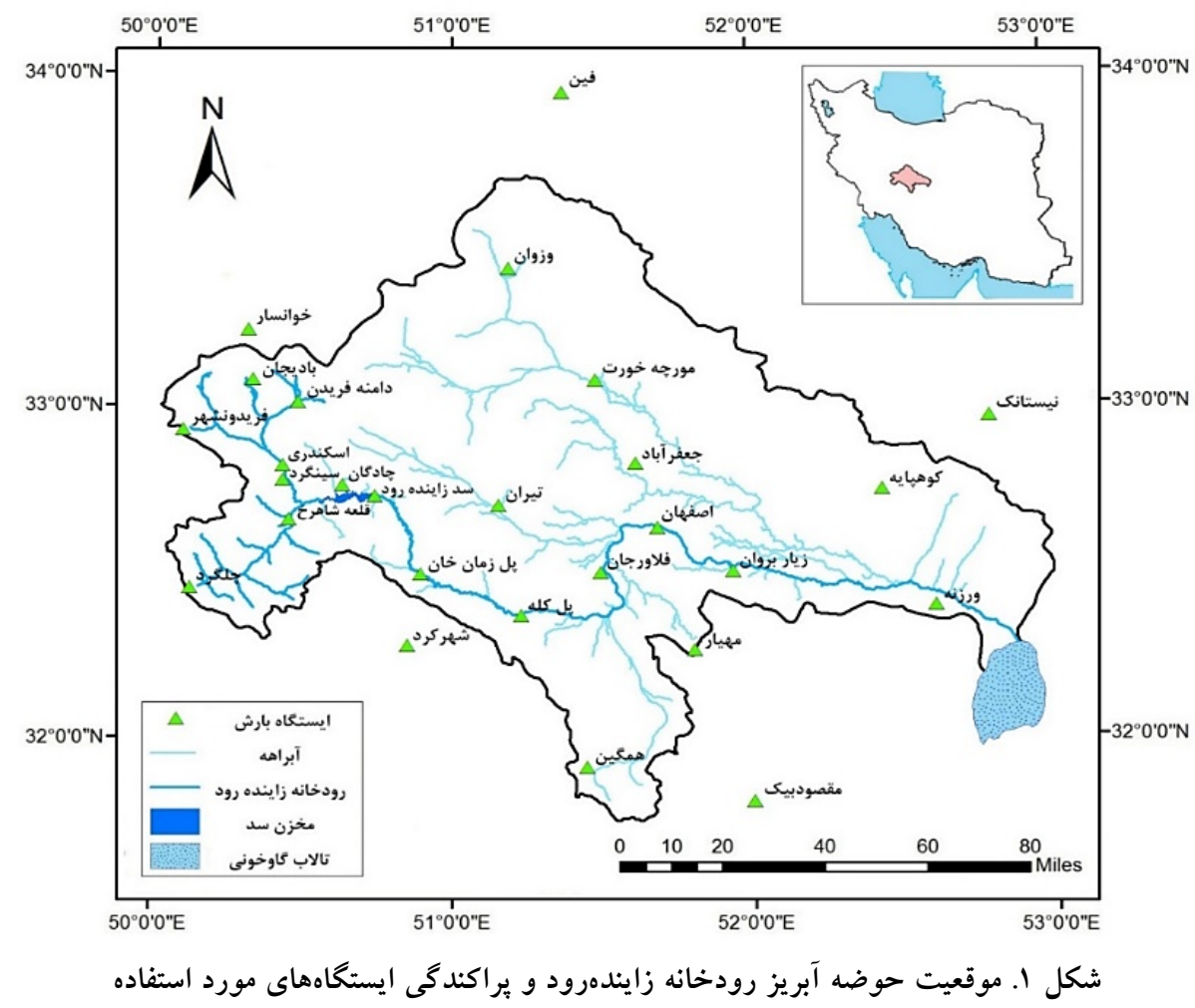

جدول ا. مشخصات ايسئاههاى مورد استفاده در مثطقه مطالعاتى

\begin{tabular}{|c|c|c|c|c|c|c|c|c|c|c|c|}
\hline $\begin{array}{l}\text { ارتفاع } \\
\text { (مثتر) }\end{array}$ & جير افبايى & جغر افبايى & نونَ & ابستكاء & تيسماره & $\begin{array}{l}\text { ارتفاع) } \\
\text { (مثر) }\end{array}$ & جغرافيابي & جغرافيايى & نوقع ابستكاء & ابستَّاه & ابستماه \\
\hline rlo & $r Y^{\circ}+\varphi^{\prime}$ & $00^{\circ} r 0^{\prime}$ & كليماتولوزي & سبنكرد & 10 & 1000 & $r Y^{\circ} \mu^{\prime}$ & $01^{\circ}+1^{\circ}$ & سبنويتيك & الحفهان & 1 \\
\hline ropq & $r Y^{\circ} 19^{\prime}$ & $00^{\circ} 01^{\circ}$ & سبنويتبك & شهركرد & 19 & $r|f|$ & $T Y^{\circ}+q^{\circ}$ & $00^{\circ} \mathrm{ro}$ & بارانسنجي & اسكندزى & r \\
\hline 1.00 & $M^{\circ} \Delta \varphi^{\circ}$ & $01^{\circ} \mathrm{KY}^{\circ}$ & بارانسـنجى & فين & iv & $r m$ & $m^{\infty} \circ f^{\prime}$ & $00^{\circ} 19^{\circ}$ & كليماتولوزي & باديجان & $r$ \\
\hline$r \ll q$. & $r T^{\circ} \Delta 0^{\circ}$ & $00^{\circ} \cdot 9^{\prime}$ & كلبماتولوزى & فريدزنثهر & $M$ & MOV & rYoró & $00^{\circ} \Delta f^{\circ}$ & تبخيرسنجي & يِل زمان خحان & 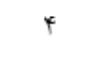 \\
\hline$r \circ \wedge 1$ & rra' & $00^{\circ} \mathrm{rV}$ & تبخير & قلحه شـاهرخ & 19 & IVOA & $r Y^{\circ} \mathrm{Yr}^{\circ}$ & $01^{\circ}$ & بارانسنجي & يل كلد. & 0 \\
\hline rIT. & $r r^{\circ} \times r^{\prime}$ & $00^{\circ} 44^{\prime}$ & تبخيرسنجى & سيد زاينده رود & ro & Who & rYo $\mathrm{Kr}^{\circ}$ & $01^{\circ} \circ 9^{\prime}$ & تبخيرسنجي & تيران & 9 \\
\hline IAVG & $M T^{\circ} \times Q^{\prime}$ & $\Delta r^{\circ} r \varphi^{\prime}$ & تبخيرسنجى & كوهيابِ & rI & 10NT & $r Y^{\circ}+q^{\circ}$ & $01^{\circ} \mathrm{rV}$ & بارانسنجي & جعفر آباد & v \\
\hline 1999 & $m^{\circ}$ of & $01^{\circ} \mathrm{KA}$ & تبخيرسنجى & مورجه خحورت & rt & $r 10$ & $r r^{\circ}+q^{\prime}$ & $00^{\circ} \mathrm{rV}$ & كليماتولوزي & جادكّان & $\wedge$ \\
\hline 191. & $r^{\circ} \Delta \Lambda^{\prime}$ & $\Delta r^{\circ}+A^{\prime}$ & تبخيرسنيجى & نيستانك & rr & TrVY & $r Y^{\circ} r V^{\circ}$ & $\Delta 0^{\circ} \circ V^{\prime}$ & بارانسـنجى & حلذِرد & 9 \\
\hline 1990 & $r Y^{\circ} 19^{\prime}$ & $01^{\circ}+\Lambda^{\prime}$ & تبخيرسنجى & مهيار & re & rro. & "rו & $00^{\circ} 19^{\circ}$ & كلبماتولوزي & خحوانسار & 10 \\
\hline $19 v 9$ & $M M^{\circ}+\Lambda^{\circ}$ & $\Delta r^{\circ} \ldots$ & بارانسـنجي & مثصمودبيك & ro & 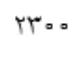 & $m=1$ & $00^{\circ} r \Lambda^{\circ}$ & كلبماتولموزى & دامنه فريدن & 11 \\
\hline 1811 & Mo ro & $01^{\circ} 11^{\circ}$ & تبخيرسنيم & وزوان ميمه & re & IATr & $r T^{\circ} r 0^{\circ}$ & $01^{\circ} r=$ & تبخيرسنجى & زنره فالزرجان & ir \\
\hline \multirow[t]{2}{*}{ Iro. } & rY Y Y & $\Delta r^{\circ} r V^{\prime}$ & كليماتولوزي & ل وزنته & rV & $10 \%$ & rro ro. & $01^{\circ} \Delta 9^{\prime}$ & بارانسنجي & زيار & ir \\
\hline & & & & & & $r 10^{\circ}$ & $r 1^{\circ} \Delta 0^{\circ}$ & $01^{\circ} \mathrm{Tr}$ & كليماتولوزيى & همكين & 14 \\
\hline
\end{tabular}


هاى بـارش، نرمـال بــودن توزيـع احتمـالاتى آنهـا بـا آزمـون

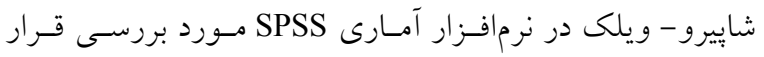

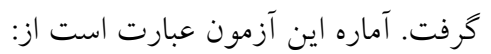
$S=\frac{\left(\sum_{i=1}^{N} A_{i} X_{i}\right)^{r}}{\sum_{i=1}^{N}\left(X_{i}-\bar{X}\right)^{r}}$ ثابتهاى A از رابطه زير بهدست مى آيند: $\left(\mathrm{A}_{1}, \ldots, \mathrm{A}_{\mathrm{n}}\right)=\frac{\mathrm{M}^{\mathrm{T}} \mathrm{V}^{-1}}{\left(\mathrm{M}^{\mathrm{T}} \mathrm{V}^{-1} \mathrm{~V}^{-1} \mathrm{M}\right)^{1 / r}}$

$\mathrm{M}=\left(\mathrm{M}_{1}, \ldots, \mathrm{M}_{\mathrm{n}}\right)^{\mathrm{T}}$

كـه در روابـط فــوق، X آمـاره ترتيبسى،

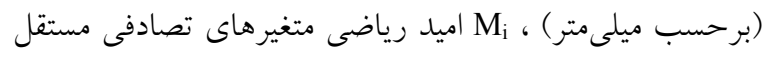

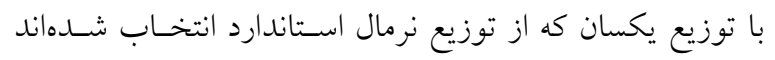

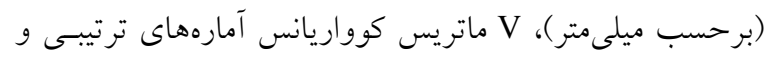

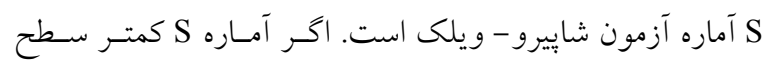

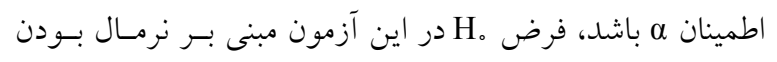

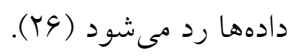

روشهاى درونيابى مكانى مورد مطالعه در اين يزوهش از جهار روش درونيابى مكسانى قطعى شـامل

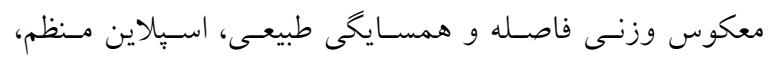

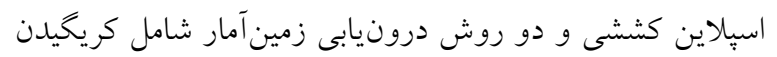
معمولى، كريخيدن عام در محيط نرمافزار ArcGIS استفاده شد.

\section{روش معكوس وزنى فاصله}

معكوس وزنى فاصله از روش هاى معمول و بر كاربرد درونيابى

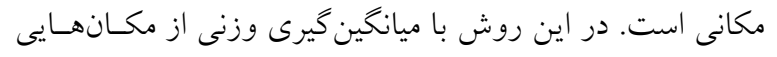

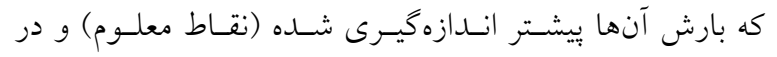

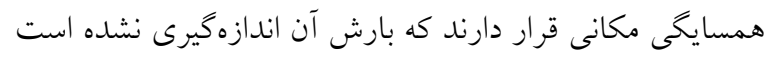

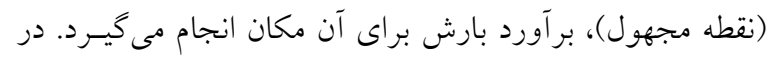

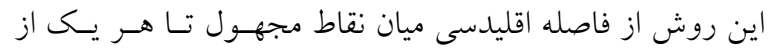

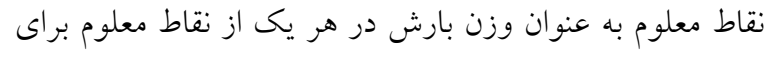

آزمون مانايى دادهها

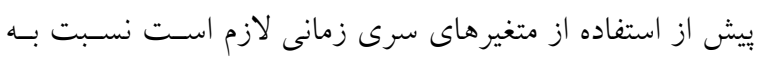

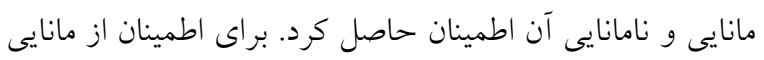

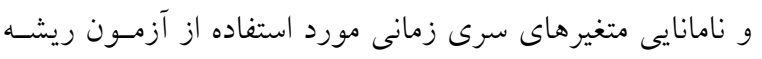

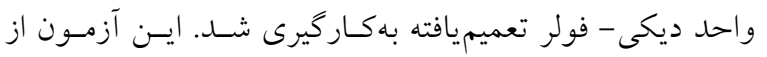

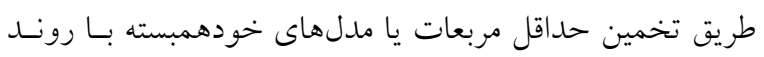

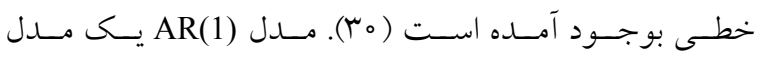
خودهمبسته با تأخير يك است و عبارت است ازد ازئ $X_{t}=\rho X_{t-1}+\varepsilon_{t} \quad t=1, r, \ldots, N$

كه در اين رابطه،

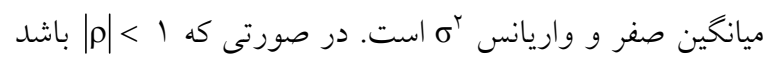

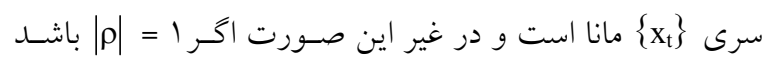

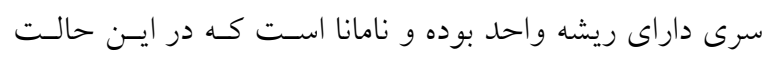

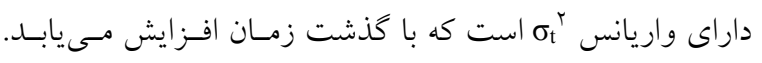
مقدار م با استفاده از روش حداكثر درستنمايى بهصورت زئ زير $\rho=\left(\sum_{t=r}^{N} X_{t-1}^{r}\right)^{-1} \cdot \sum_{t=r}^{N} X_{t} \cdot X_{t-1}$

$\mathrm{T}=\frac{\rho-1}{\sigma_{\mathrm{p}}}$

در روابط فوق، مَ خطاى اسـتاندارد تخمسين حسداقل مربعـات

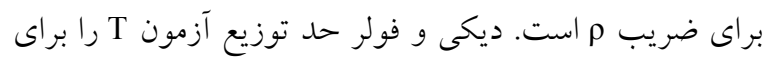

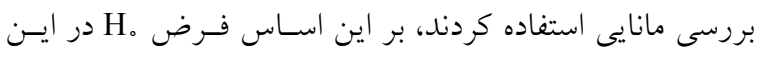

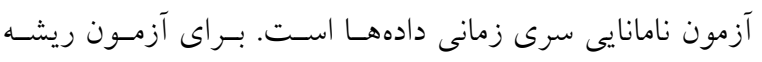

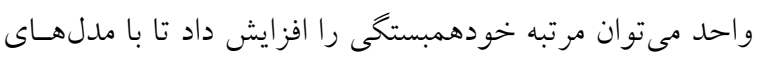
عمومى ARMA(p,q) با مرتبههاى نامعين تطبيق داده شود (N).

\section{آزمون نرمال بودن دادهها}

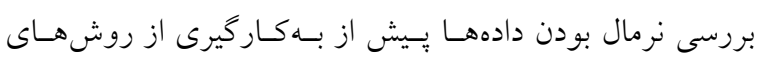

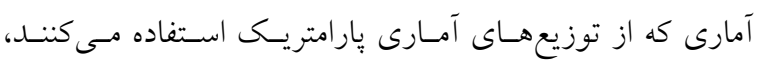

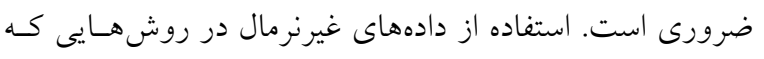

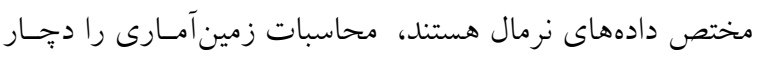

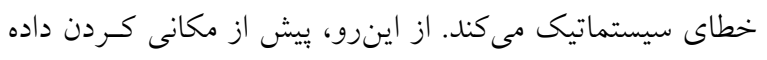


انتهاى فواصل برآورد مىشوند كه بر دو فرض اساسى استوار

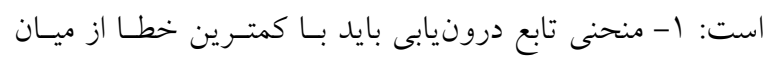

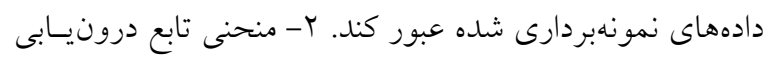

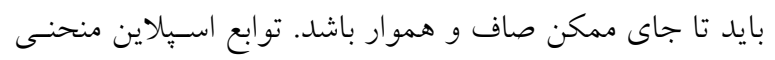

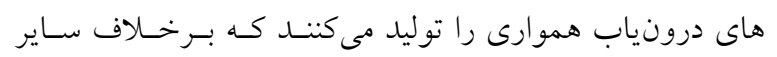

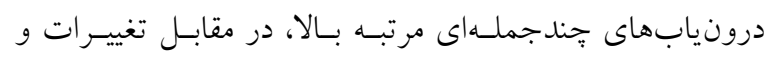

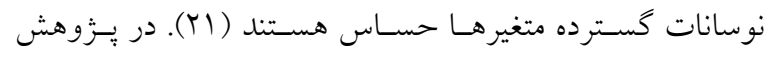
حاضر از دو روش اسيلاين از نوع كششى و منظم استفاده شد.

\section{الف) اسِلاين كششى}

در روش اسبلاين كششى Z(x,y) بهعنوان تابعى معرفى مى شود

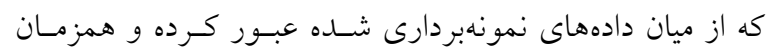

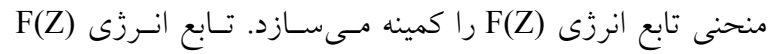
بهصورت رابطه زير قابل محاسبه است:

$F(Z)=\iint_{R^{r}}\left\{\begin{array}{l}\varphi^{r}\left(Z_{x}^{r}+Z_{y}^{r}\right) \\ +\left(Z_{x x}^{r}+r Z_{x y}^{r}+Z_{y y}^{r}\right)\end{array}\right\} d x d y$

همجنين تابع Z بهصورت زير تعريف مىشود:

$\mathrm{Z}(\mathrm{x}, \mathrm{y})=\sum_{\mathrm{i}=1}^{\mathrm{N}} \mathrm{L}_{\mathrm{i}} \mathrm{R}\left(\mathrm{r}, \mathrm{r}_{\mathrm{i}}\right)+\mathrm{T}(\mathrm{x}, \mathrm{y})$

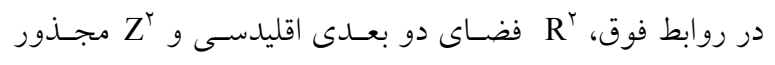
مشتق مرتبه اول و مشتق مرتبه دوم تابع N Z تعداد نقاط نمونه،

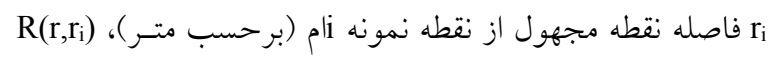

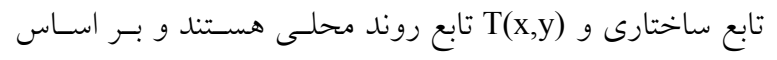
نوع روش اسيلاين از رابطه زير تعيين مى شود:

$\mathrm{T}(\mathrm{x}, \mathrm{y})=\mathrm{C}$

ضريب L در رابطه (م) ضريب حل معادلات خطسى اسـت و

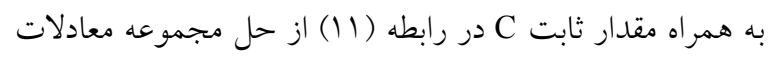

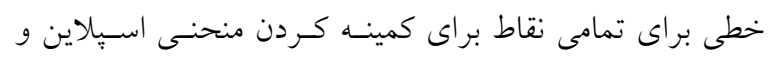

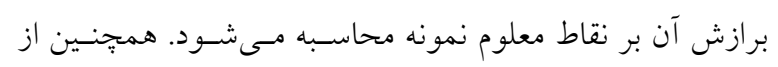

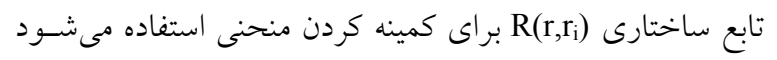
و از رابطه زير قابل محاسبه است: $R\left(r, r_{j}\right)=-\frac{1}{r \pi \varphi^{r}}\left[\ln \left(\frac{D_{j} \varphi}{r}\right)+C+K_{o}\left(D_{j} \varphi\right)\right]$

در رابطه فوق، Kم تابع تعديل مرتبـه صـفر بسـل، Dاصـله
بيشبينى نقاط مجهول و از توان در معكوس فاصسله بـهمنظسور

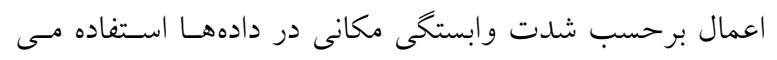

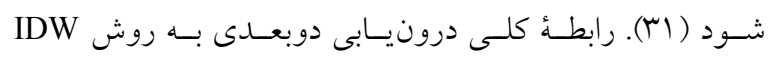
بهصورت رابطه (V) قابل تعريف است: $\mathrm{Z}^{*}(\mathrm{x}, \mathrm{y})=\frac{\sum_{\mathrm{i}=1}^{\mathrm{N}} \mathrm{Z}_{\mathrm{i}} \mathrm{D}_{\mathrm{ij}}^{-\mathrm{P}}}{\sum_{\mathrm{i}=1}^{\mathrm{N}} \mathrm{D}_{\mathrm{ij}}^{-\mathrm{P}}}$

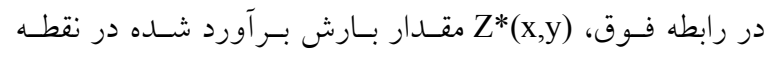

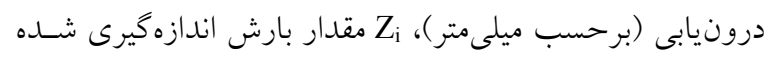

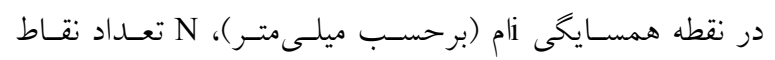

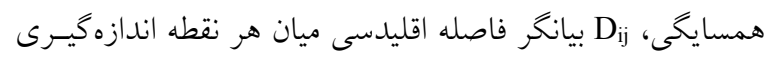

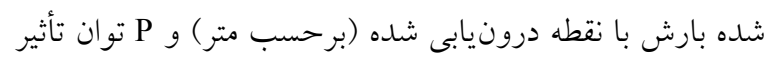

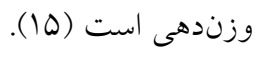

\section{روش همسايكى طبيعى}

روش همسايخى طبيعى بر مبناى نزديكترين نقاط نمونه كـه در

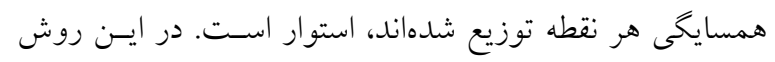

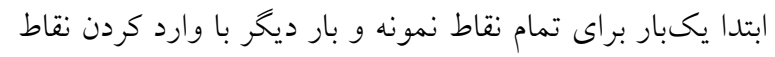

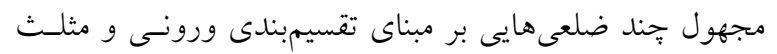

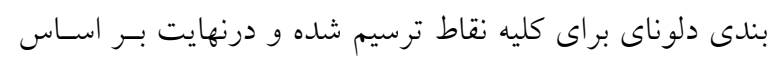

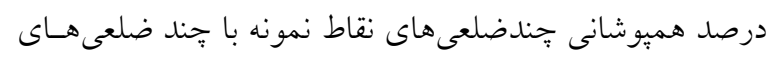

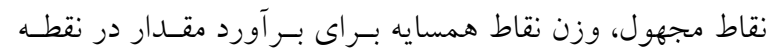

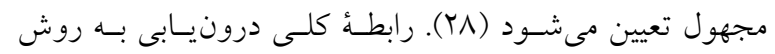

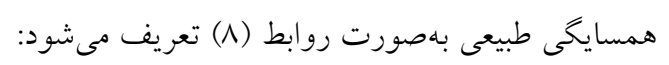
$\mathrm{Z} *(\mathrm{x}, \mathrm{y})=\frac{\sum_{\mathrm{i}=1}^{\mathrm{N}} \mathrm{A}_{\mathrm{i}} \times \mathrm{Z}_{\mathrm{i}}}{\sum_{\mathrm{i}=1}^{\mathrm{N}} \mathrm{A}_{\mathrm{i}}}$ در رابطه فوق، Z(x,y) مقدار نقطـه درونيـابى شــده (برحسبب

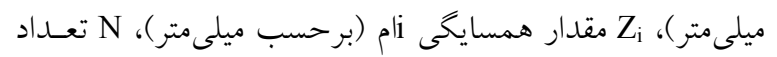

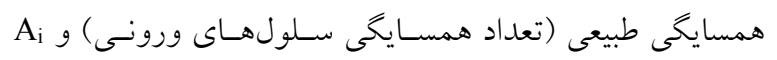

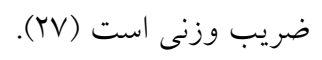

\section{روش اسبلاين}

در روش اسيلاين مقادير نقاط مجهول از برازش تابعى بر مقادير

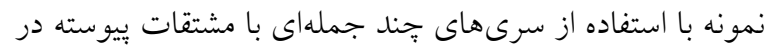


مقادير اندازهگيرى شده با توجه به توزيع مكانى مقــادير بــرآورد

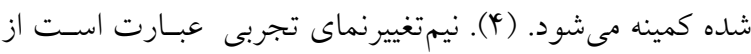

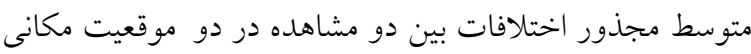

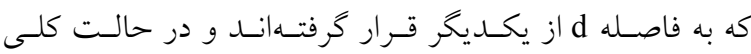

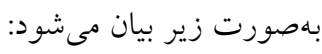

$\lambda *(\mathrm{~d})=\frac{1}{r \mathrm{~N}(\mathrm{~d})} \sum_{\mathrm{i}=1}^{\mathrm{N}(\mathrm{d})}\left[\mathrm{Z}\left(\mathrm{x}_{\mathrm{i}}\right)-\mathrm{Z}\left(\mathrm{x}_{\mathrm{i}}+\mathrm{d}\right)\right]^{r}$

در رابطه فوق، (d)* $\lambda$ نيمتغييرنماى تجربى، Z(x) مقدار بارش

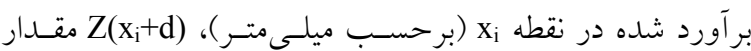

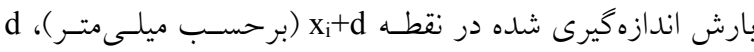

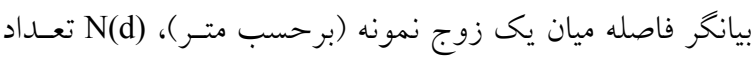

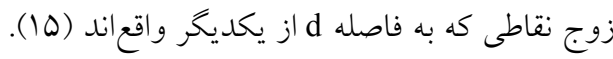

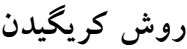

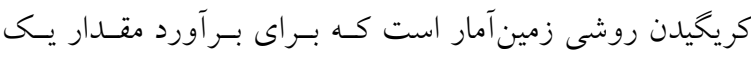

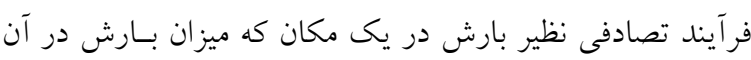

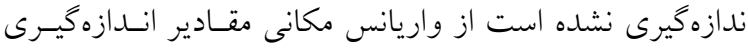

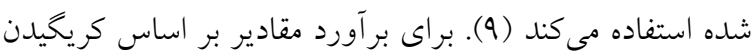

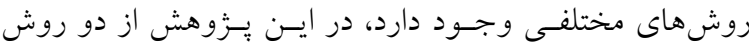

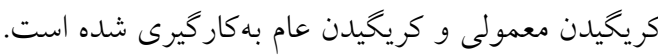

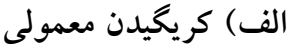

در اين روش فرض مىشود كه روند تغييرات ميانخين بـارش

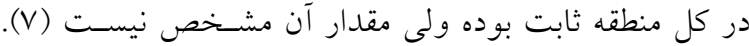

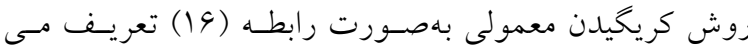

$\mathrm{Z} *\left(\mathrm{x}_{\mathrm{i}}\right)=\sum_{\mathrm{i}=1}^{\mathrm{N}} \lambda_{\mathrm{i}} \mathrm{Z}\left(\mathrm{x}_{\mathrm{i}}\right)$

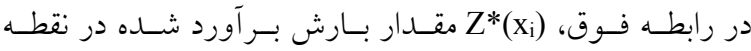

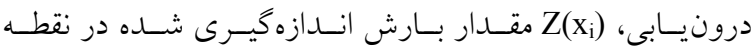
همسايخى il (برحسب ميلىمتر)،

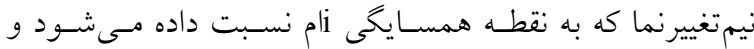

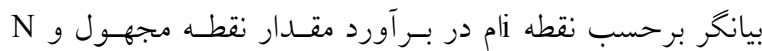

ميان نقطه نمونه و نقطه برآوردشده (برحسب متر) و C مقدار

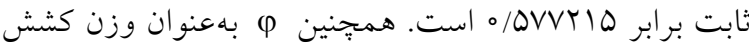
تعريف مىشود و مى تواند مقاديرى بيشتر از يك داشته باشــ

$$
\text { ب) اسبلاين منظم }
$$

در ميان تمـامى روشهـاى اسـيلاين، روش اسـهِلاين مـنظم بـا

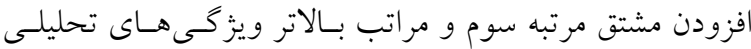

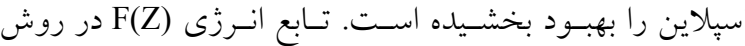
اسبلاين منظم از رابطه زير حاصل مىشود:

$F(Z)=\iint_{R^{r}}\left\{\begin{array}{l}\left(Z_{x x}^{r}+r Z_{x y}^{r}+Z_{y y}^{r}\right) \\ +\tau^{r}\left(Z_{x x x}^{r}+\ldots\right)\end{array}\right\} d x d y$

همجنين تابع ساختارى R(r,rir در اين روش از رابطه زير قابـل

$R\left(r, r_{j}\right)=\frac{1}{r \pi}\left\{\begin{array}{l}\frac{D_{j}^{r}}{r}\left[\ln \left(\frac{D_{j}}{r \tau}\right)+C-1\right] \\ +\tau^{r}\left[K_{\circ}\left(\frac{D_{j}}{\tau}\right)+C+\ln \left(\frac{D_{j}}{r \pi}\right)\right]\end{array}\right\}$

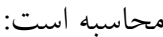

در رابطه فوق، Ko تابع تعديل مرتبه صفر بسل و Dاصله ميان

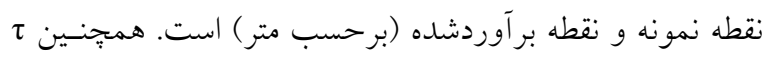
بلهنوان وزن مشتق مرتبه سوم در تابع انرزى تعريف مىشـود و مى تواند مقاديرى بين صفر و ه/ه داشته باشد (Yم).

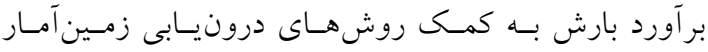
نيازمند مدلى براى بررسى تغييرات واريـانس مكـانى بـارش بــه زاى فواصل نمونه گيرى براى محاسبه وزن نقاط نمونسهبــردارى شده براى درون يابى بارش در نقطه نمونهبـــدارى نشــده اسـت. بدينمنظور از مدل نيمتغييرنماى تجربى استفاده مى شوده.

نيم تغييرنماى تجربى نيمتغييرنما مهم ترين ابزار شناسايى ساختار و همبستكى مكـانى بين دادهها اسـت. در روشهــاى زمسين آمـار از مــلدهـاى نسيم تغييرنماى تجربى كوناكون (كروى، نمايى و ...) بهمنظور نمايش رون

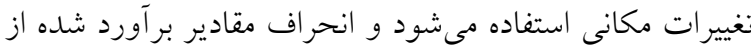


خطاى مطلق اريب بــراى ارزيـابى دقـت روشهـاى درونيـابى

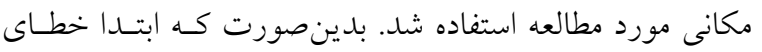

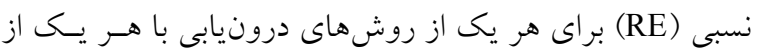

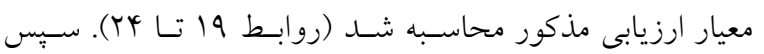

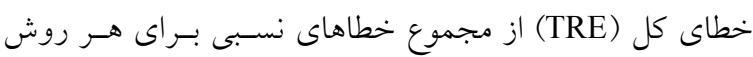

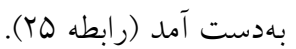

$$
\begin{aligned}
& \operatorname{MBE}\left(Z_{\mathrm{m}}\right)=\frac{1}{N} \sum_{\mathrm{i}=1}^{N}\left(Z_{\mathrm{m}}\left(\mathrm{x}_{\mathrm{i}}\right)-\mathrm{Z}_{\mathrm{o}}\left(\mathrm{x}_{\mathrm{i}}\right)\right) \\
& \operatorname{MAE}\left(\mathrm{Z}_{\mathrm{m}}\right)=\frac{1}{\mathrm{~N}} \sum_{\mathrm{i}=1}^{N}\left|\mathrm{Z}_{\mathrm{m}}\left(\mathrm{x}_{\mathrm{i}}\right)-\mathrm{Z}_{\mathrm{o}}\left(\mathrm{x}_{\mathrm{i}}\right)\right| \\
& \operatorname{RMSE}\left(\mathrm{Z}_{\mathrm{m}}\right)=\sqrt{\frac{1}{\mathrm{~N}} \sum_{\mathrm{i}=1}^{\mathrm{N}}\left(\mathrm{Z}_{\mathrm{m}}\left(\mathrm{x}_{\mathrm{i}}\right)-\mathrm{Z}_{\mathrm{o}}\left(\mathrm{x}_{\mathrm{i}}\right)\right)^{r}} \\
& \operatorname{RE},\left(\mathrm{Z}_{\mathrm{m}}\right)=\frac{\left|\operatorname{MBE}\left(\mathrm{Z}_{\mathrm{m}}\right)\right|}{(\mathrm{N} / \mathrm{M}) \times\left(\sum_{\mathrm{m}=1}^{\mathrm{M}}\left|\operatorname{MBE}\left(\mathrm{Z}_{\mathrm{m}}\right)\right|\right)}
\end{aligned}
$$

$$
\operatorname{RE}_{\Upsilon}\left(Z_{\mathrm{m}}\right)=\frac{\left|\operatorname{MAE}\left(Z_{\mathrm{m}}\right)\right|}{(\mathrm{N} / \mathrm{M}) \times\left(\sum_{\mathrm{m}=1}^{\mathrm{M}}\left|\operatorname{MAE}\left(Z_{\mathrm{m}}\right)\right|\right)}
$$

$$
\operatorname{RE}_{\Gamma}\left(Z_{\mathrm{m}}\right)=\frac{\left|\operatorname{RMSE}\left(Z_{\mathrm{m}}\right)\right|}{(1 / \mathrm{M}) \times\left(\sum_{\mathrm{m}=1}^{\mathrm{M}}\left|\operatorname{RMSE}\left(Z_{\mathrm{m}}\right)\right|\right)}
$$

$\mathrm{TRE}=\sum_{\mathrm{i}=1}^{r} R \mathrm{E}_{\mathrm{i}}$

كه در روابط فوق، (بر حسب ميلىمتر)، Z Z (X) مقدار مشاهده شده بارش در نقطه

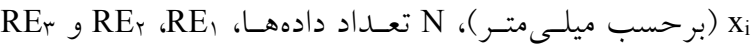
بهترتيب خطاى نسـبى بـا معيارهـاى MBE و MAE MMSE بوده و TRE خطاى نسـبى كـل (برحسـب ميلسىمتر ) اسـت. انديس m در روابط بالا معرف هر يك از روشهاى درونيابى مكانى مورد استفاده و M تعداد كـل ايسن روشهــا اسـت. در

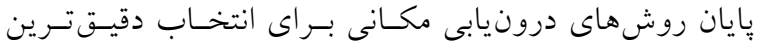
روش رتبهبندى شدند و روشى كه از كمترين خطاى نسبى كل و بهترين رتبه برخوردار بود، بهعنوان روش يهنهبندى مناسـب براى حوضه معرفى شد.
تعداد كل نقاط نمونه است (Yq).

$$
\text { ب) بريخيدن عام }
$$

روش كريخيدن عام تلفيقى از روش كريخيدن ساده بههمراه يك

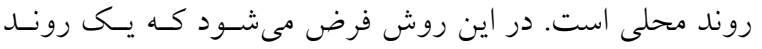
كلى و غالب در بين مقادير نقاط نمونهبردارى شده وجـود دود دارد

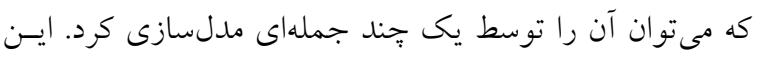

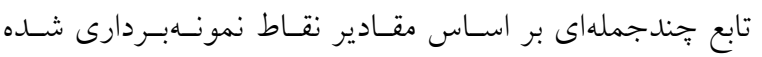
مدلسازى مىشود. بـر اسـاس فـرض تغييـريـذيرى ناحيـهاى، تغييرات مكانى هر متغير Z با جمع دو مؤلفه اصلى بيان مىشود:

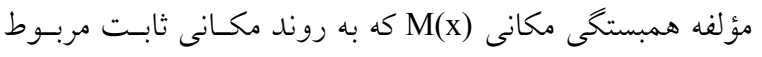

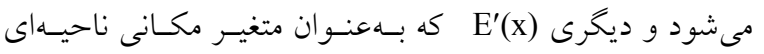
شناخته مىشود (Y). متغير Z در مكان X بهصورت زير تعريـف خواهد شد: $\mathrm{Z}(\mathrm{x})=\mathrm{M}(\mathrm{x})+\mathrm{E}^{\prime}(\mathrm{x})$ در كريخيدن عام فرض بر اين است كه ميـانخين نقـاط متغيــر و

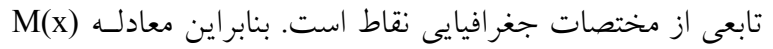
بهورت زير بيان مىشود: $\mathrm{M}(\mathrm{x})=\sum_{\mathrm{i}=1}^{\mathrm{N}} \mathrm{A}_{\mathrm{i}} \mathrm{P}_{\mathrm{i}}(\mathrm{x})$ كه در رابطه فوق، Z(x) مقدار نقطه درونيابى شـده (برحسبـ ميلى متر)، A روند محلى، (x) تابعى از مختصات جغر افيـايى نقاط (معادلات روند) و N تعداد نقاط نمونهبردارىشـده اسـت

عموماً براى درونيابى با روش كريخيدن مدل نيمتغييرنمايى كه بهترين برازش را بر نقاط نمونسهـــردارىشـده داشـته باشـد، انتخاب مىشود (4). در يزوهش حاضر بهمنظور بررسى دقيقتر براى برآورد وزن آمـارى از نـيمتغييرنماهــاى كـروى، دايـرهاى، نمايى، گوسى و خطى به كار گيرى شد.

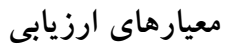
در اين يزوهش با به كارگيرى از تكنيـى اعتبـار متقابـل، از سـه شاخص ريشه ميانخين مربعات خطا، ميـانخين خطـاى اريسب و 


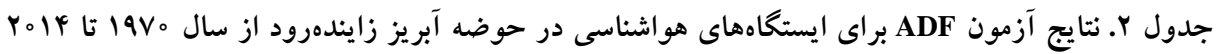

\begin{tabular}{|c|c|c|c|c|c|c|c|}
\hline$T_{90 \%}$ & $\mathrm{~T}$ & ايستخاه & & $\mathrm{T}_{9 \Delta \%}$ & $\mathrm{~T}$ & ايستخاه & \\
\hline$-0 / 9$ & $-10 / \pi$ & وزوان ميمه & 10 & $-0 / 9$ & $-10 / \pi$ & اصفهان & 1 \\
\hline$-0 / 9$ & $-10 / 1$ & مورجه خورت & 19 & $-0 / 9$ & $-11 / 9$ & شهر كرد & r \\
\hline$-0 / 9$ & $-1 Y / 0$ & كوهيايه & IV & $-0 / 9$ & $-10 / \mu$ & جاد گَان & $r$ \\
\hline$-0 / 9$ & $-\mid Y / 1$ & مهيار & 11 & $-0 / 9$ & $-10 / \pi$ & همخين & $r$ \\
\hline$-0 / 9$ & $-11 / r$ & تيران & 19 & $-0 / 9$ & $-10 / \mu$ & فريدو نشهر & 0 \\
\hline$-0 / 9$ & $-11 / 4$ & نيستانك & ro & $-0 / 9$ & $-11 / 1$ & خوانسار & 4 \\
\hline$-0 / 9$ & $-11 / \pi$ & يّل كله & rI & $-0 / 9$ & $-\Lambda / \Lambda$ & باديجان & V \\
\hline$-0 / 9$ & $-11 / 4$ & زيار بروان & Tr & $-0 / 9$ & $-11 / 4$ & سينگرد & $\wedge$ \\
\hline$-0 / 9$ & $-11 / 9$ & اسكندرى & r & $-0 / 9$ & $-9 / 9$ & ورزنه & 9 \\
\hline$-0 / 9$ & $-11 / 1$ & فين & TY & $-0 / 9$ & $-11 / 4$ & دامنه & 10 \\
\hline$-0 / 9$ & $-10 / 1$ & جلكرد & ro & $-0 / 9$ & $-10 / 1$ & قلعه شاهرخ & 11 \\
\hline$-0 / 9$ & $-10 / 4$ & جعفر آباد & re & $-0 / 9$ & $-11 / V$ & سد زايندهرود & ir \\
\hline \multirow[t]{2}{*}{$-0 / 9$} & $-11 / r$ & مقصودبيكى & rV & $-0 / 9$ & $-11 / r$ & زمان خان & ir \\
\hline & & & & $-0 / 9$ & $-11 / 9$ & فلاورجان & if \\
\hline
\end{tabular}

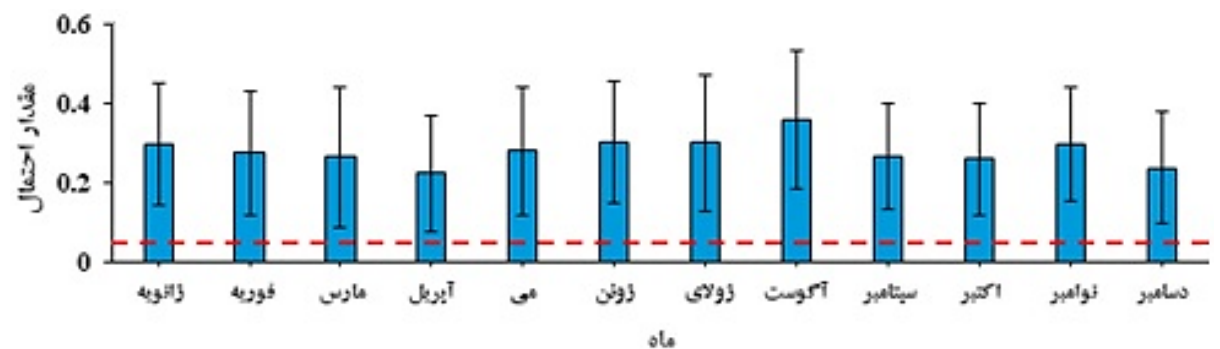

شكل r. مقادير متوسط احتمال براى آماره آزمون شاييرو - ويلك(S) در ايستخاههاى مورد مطالعه در حوضه آبريز

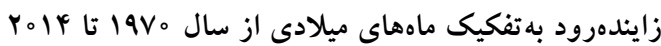

قرار گرفت. نتايج نشان داد در تمـامى مـوارد بجـز مــاهــاى خرداد، تير، مرداد و شهريور، توزيع دادهها در سطح اطمينـان

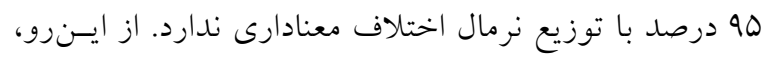

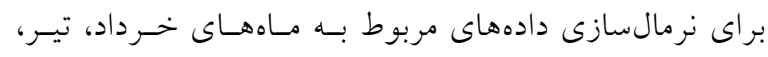

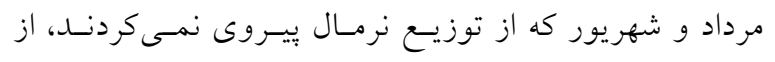

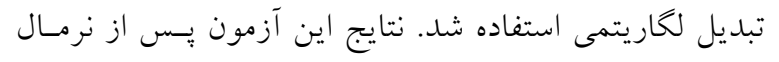

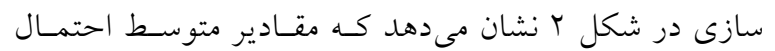

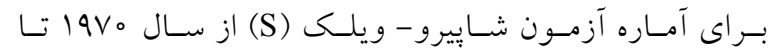

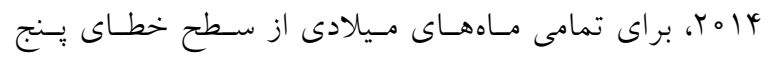

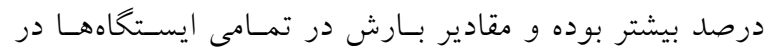
منطقه مطالعاتى با توزيع نرمال اختلاف معنادارى ندارد.

\section{نتايج و بحث} از نتايج آزمون ADF ملاحظه مىشود با توجه به اينكـه قـدر

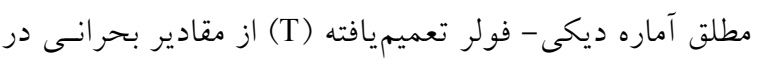

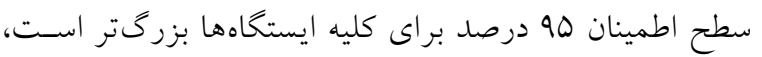
لذا اين جنين نتيجه كيرى مى شود كه كليه ايستخاههـاى مسورد

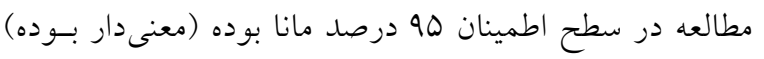
و فرض H مبنى بر وجود ريشه واحد در مقسادير بـارش بـا

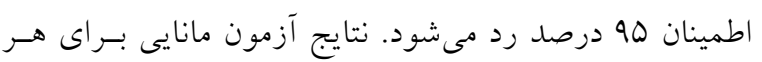
ايستخاه در جدول (r) ارائه شده است.

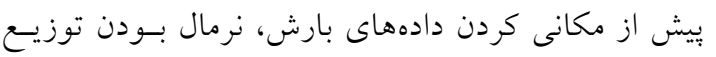

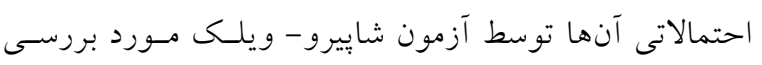




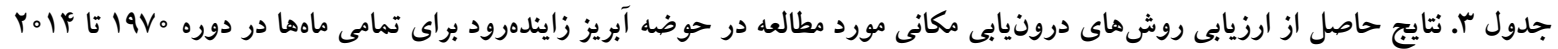

\begin{tabular}{|c|c|c|c|c|c|c|c|c|}
\hline RMSE (mm) & رتبه & MAE (mm) & 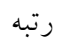 & $\operatorname{MBE}(\mathrm{mm})$ & رتبه & خطاىنسبى كل & رتبه كل & روش درونيابى \\
\hline $0 / 99$ & 14 & .191 & 14 & $\circ / 0 \circ$ & 10 & $1 / 10$ & 14 & معكوس وزنى فاصله با توان يك \\
\hline $0 / 99$ & ir & $0 / 09$ & ir & $\circ / 4 V$ & 14 & $1 / 10$ & ir & معكوس وزنى فاصله با توان دو \\
\hline.$/ 90$ & Ir & $\circ / \Delta \wedge$ & ir & $0 / 49$ & ir & $1 / 0 \wedge$ & ir & معكوس وزنى فاصله با توان سه \\
\hline.$/ 94$ & 10 & $\circ / D V$ & 11 & $\circ / 4 \Delta$ & 11 & $1 / 0 \mathrm{~V}$ & 10 & معكوس وزنى فاصله با توان جهار \\
\hline.$/ 94$ & 11 & $\circ / Y^{4}$ & 10 & $\circ / 09$ & ir & $1 / \circ \mathrm{V}$ & 11 & معكوس وزنى فاصله با توان ينج \\
\hline o/Ar & 1 & $0 / Y Y$ & 1 & $\circ / 1 \circ$ & 1 & $\circ / \mu q$ & 1 & كى طبيعى \\
\hline $1 / 09$ & 10 & $0 / 94$ & 10 & $\circ / 4 \Delta$ & 10 & $1 / 1 \mathrm{~V}$ & 10 & اسِيلاين (منظم) \\
\hline$\circ / 90$ & $\wedge$ & $\circ / D Y$ & $\wedge$ & $\circ / 4 \circ$ & r & $1 / 00$ & r & اسِلاين (كششى) \\
\hline$\circ / 19$ & $v$ & $\circ / D Y$ & 4 & $0 / 4 T$ & 9 & $1 / 01$ & $\wedge$ & كريخيدن (كروى) \\
\hline $0 / 19$ & 0 & $\circ / \Delta Y$ & 0 & OMT & 0 & $1 / 01$ & 9 & كريخيدن (دايرهاى) \\
\hline$\circ / \wedge 9$ & $r$ & $\circ / \Delta r$ & r & O/AT & v & $1 / 01$ & 0 & كريخيدن (نمايى) \\
\hline.$/ 94$ & 9 & $\circ / 09$ & 9 & $0 / 4$ & 9 & $1 / 00$ & 9 & كريخيدن (كوسى) \\
\hline$\circ / 19$ & 9 & $\circ / \Delta Y$ & v & o/At & r & $1 / 01$ & $v$ & كريخيدن (خطى) \\
\hline$\circ / \wedge \mathrm{V}$ & r & $\circ / \Delta r$ & $r$ & $0 / 4 T$ & $\wedge$ & $1 / 00$ & c & كريخيدن (با روند خطى) \\
\hline$\circ / \Lambda Y$ & r & $\circ / 0 \circ$ & r & (r/ & r & $0 / 90$ & r & كريخيدن (با روند درجه دوم) \\
\hline
\end{tabular}

روند درجه دوم با خطـاى مطلـت اريسب •0/ه از بـالاترين دقـت برخوردار بود. اين درحالى است كه تمـامى روشهـاى كريخيـدن

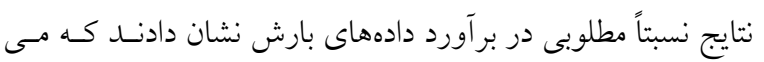
توان اين موضوع را ناشى از ماهيت احتمالاتى بـارش دانسـت. در

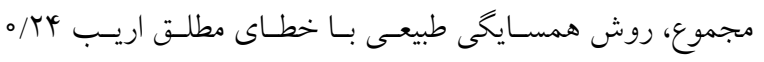
بهترين برآورد را در ميان تمامى روشهاى مـورد مطالعسه داشـت. جدول (r) نتايج حاصل از ارزيـابى روشهـاى درونيـابى مـورد مطالعه را با بهكارگيرى از هر سـه معيـار MAE M M و RME

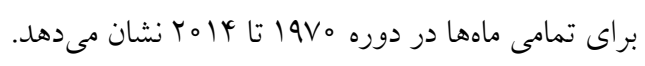
شكل ب نتايج حاصل از ارزيابى روشهاى درونيابى مكانى بـا استفاده از معيار خطاى مطلق ميانخين رادر حوضه آبريز زايندهرود

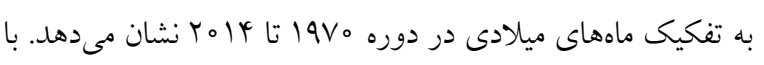
توجه به اينكه بيشتر بارشها در حوضه زايندهرود از ماههـاى مهـر تا ارديبهشت است، بهجز براى ماههاى تابستان كه كمتـرين ميـزان بارش را در حوضه شاهد هستيم به وضوح قابل مشاهده است كـه

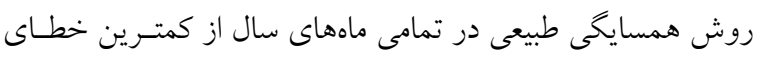
مطلق ميانخين در ميان ساير روش هما برخوردار است.
ارزيابى روشها نتايج حاصل از درونيابى دادهاى ميانخين بارش ماهانه نشـان داد روشهاى معكوس وزنى فاصله با توانهاى مختلف در مقايسه بـاـ

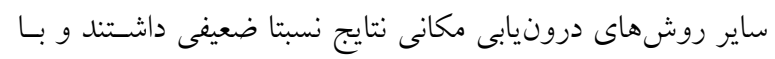
توجه به خطاى نسبى كل محاسبه شده از مجموع خطاهاى نسـبى

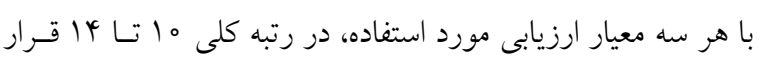
كرفتند. روش معكوس وزنى فاصله با توان لأ و معكوس وزنى بـا

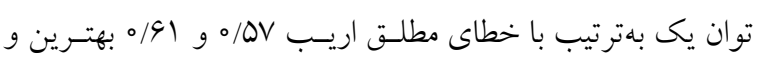

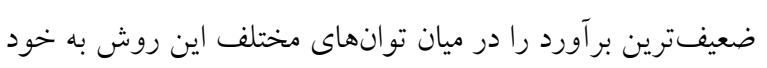

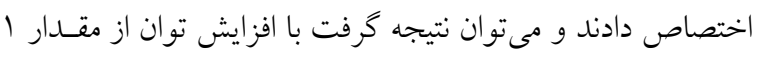

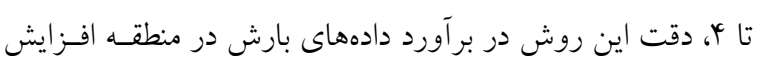
مىيابد و در مقدار توان جهار به بيشـترين ميـزان دقـت رسـيده و سبس روند كاهشى مىشود. روش اسيالاين كششى با رتبه سـه در مقايسه با نوع منظم اين روش كه ضـعيفتـرين دقـت را در ميـان تمامى روشها داشت، دقت بالاترى را نشان داد. در ميان مدلهاى

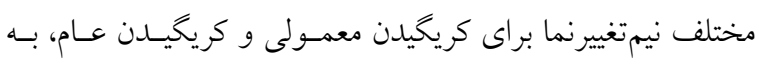
ترتيب كريخيدن نمايى با خطاى مطلق اريب \&ه/ه و كريخيـدن بـا 

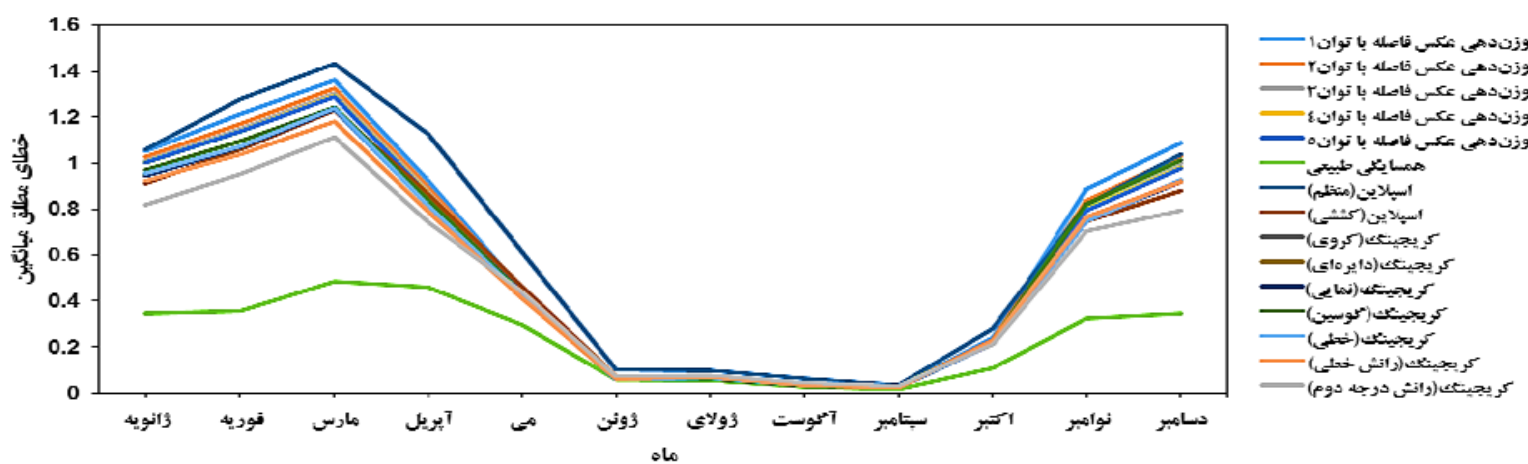

شكل r. نتايج ارزيابى روشهاى درونيابى مكانى مورد مطالعه در حوضه آبريز زايندهرود به تفكيك ماههاى ميلادى در دوره بVIf
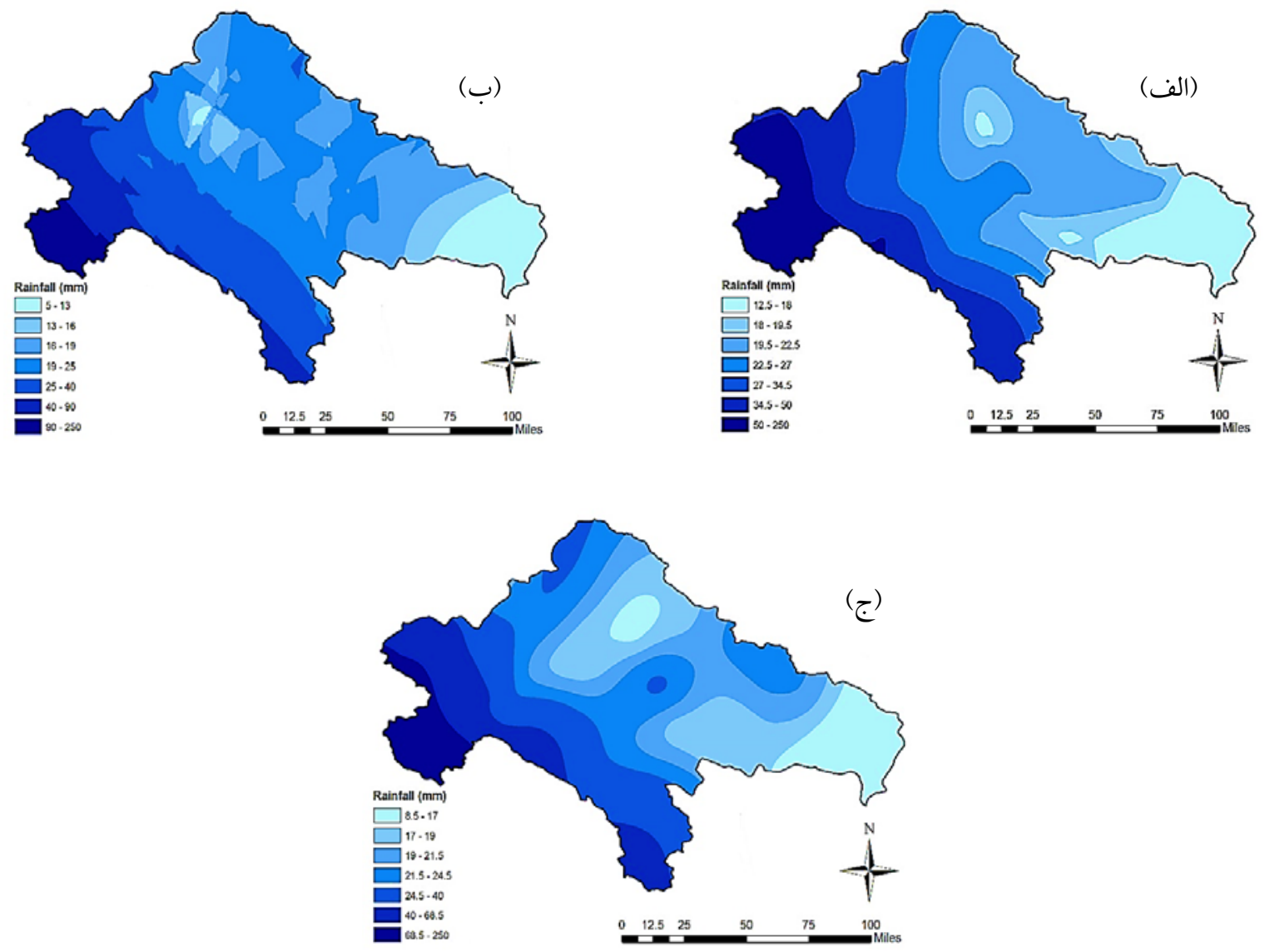

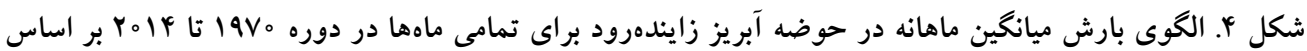
روش منطقهاى كردن: الف) همسايخى طبيعى، ب) كريجينگ عام با روند خطى درجه دوم و ج) اسيلاين كششى بـى

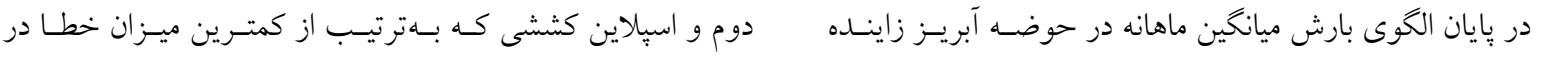

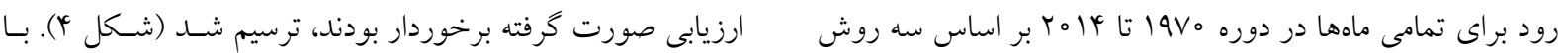
درونيابى مكانى همسايكى طبيعى، كريخيدن عام بـا رونسد درجسه توجه به نقشههاى بهنهابندى ترسيم شده آشكار است كه بيشـترين 
جنين توجيه كرد كه بـا توجسه بـه اينكسه در روش اسـيلاين بـا

افزايش مرتبـه مشـتق حساسـيت ايسن روش در برابـر تغييـرات

جزئى افزايش مىيابد و از طرفى حوضسه آبريسز زاينـدهرود در

ناحيه نيمهنشك قراركرفته است و در نـواحى وسـيعى از ايسن

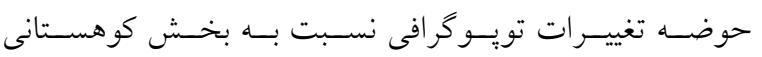

كمتراست، از اينرو در بخش اعظم حوضه آبريز زايندهرود كـه

تغييرات بارش شديد نيست، روش اسيلاين از نوع كششى بهتر

عمل مى كند. قرار گرفتن روش معكوس وزنى فاصله در مرتبـه

هاى بالاتر كوياى اين واقعيت است كه بارش يكى متغير اقليمى

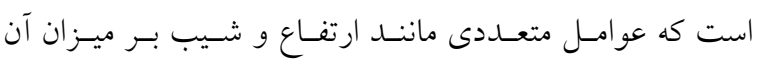

اثر گذار است و تنها متاثر از فاصله جغرافيايى نيست. بهطوركلى

مطالعات انجام شده نشان مسىدهـد كـهـ روش هـاى درونيـابى

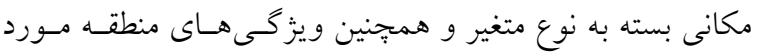

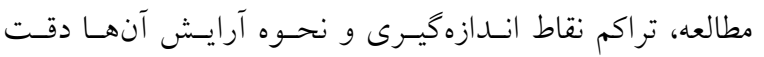

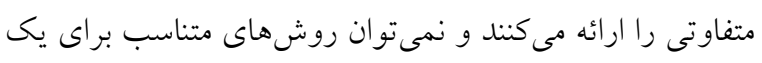

منطقه را بهراحتى به منطقه ديخر تعميم داد. لـذا لازم اسـت كـهـ

براى هر منطقه و هر متغير، بررسىهاى جداكانه انجام كرفته تـا

روش درونيابى مكانى مناسـب بــراى يــارامتر مـورد بررسى و

$$
\text { منطقه مورد نظر حاصل شود. }
$$

$$
\begin{aligned}
& \text { ميزان بارشهـا در نـواحى غـرب و جنـوبـغربسى حوضسه آبريـز } \\
& \text { رودخانه زايندهرود بود و با حركت به قسمتهاى شـرقى حوضسه } \\
& \text { ميزان بارش به تدريج كاهش مىيابد. همجنين كمترين ميزان بارش } \\
& \text { در نواحى شرقى و شمالشرقى حوضه مشاهده مىشود. } \\
& \text { نتيجه كيرى }
\end{aligned}
$$

نتايج حاصل از آزمون ADF در ايستخاه هاى مطالعاتى نشان داد

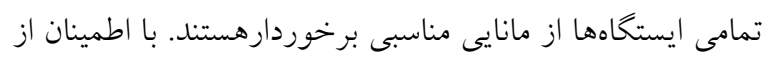
مانايى سرى زمانى ايستخاههـاى هواشناسـى در حوضسه آبريـز

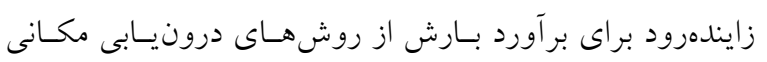
قطعى و زمين آمار استفاده شد. اين روشهــا بـا تكنيـك اعتبـار

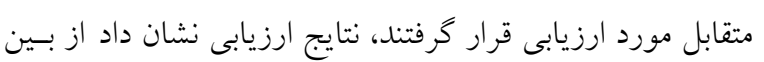
روشهاى استفاده شده براى درونيابى، روش همسايخى طبيعى از كمترين ميزان خطا با توجه به خطاى نسبى كل محاسبه شــه از مجموع خطاهاى نسبى با هر سه معيار ارزيابى شـامل MAE، RMSE و برخوردار است. روشهاى كريخيـدن عـام بـا روند درجه دوم و اسبالاين كششى نيز بس از روش همسـايخى

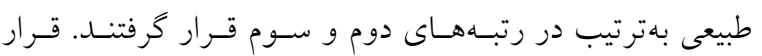
كرفتن روش اسيلاين كششى در مرتبههاى بعدى را مىتوان اين

\section{منابع مورد استفاده}

1. Abo-Monasar, A. and M. A. Al-Zahrani. 2014. Estimation of rainfall distribution for the southwestern region of Saudi Arabia. Hydrological Sciences Journal 59(2): 420-431.

2. Arowolo, A. O., A. K. Bhowmik and W. Qi and X. Deng. 2017. Comparison of spatial interpolation techniques to generate high-resolution climate surfaces for Nigeria. International Journal of Climatology 37(1): 179-192.

3. Attorre, F., M. Alfo, M. De Sanctis, F. Francesconi and F. Bruno. 2007. Comparison of interpolation methods for mapping climatic and bioclimatic variables at regional scale. International Journal of Climatology 27(13): 18251843.

4. Bhowmik, A. K. and P. Cabral. 2015. Spatially shifting temporal points: estimating pooled within-time series variograms for scarce hydrological data. Hydrology and Earth System Sciences 12: 2243-2265.

5. Bostan, P., G. Heuvelink and S. Akyurek. 2012. Comparison of regression and kriging techniques for mapping the average annual precipitation of Turkey. International Journal of Applied Earth Observation and Geoinformation 19(1): 115-126.

6. Burrough, P. A. and R. A. McDonnell. 2000. Principles of Geographical Information Systems. Oxford University Press, UK.

7. Dingman, S. L., D. M. Seely-Reynolds and R. C. Reynolds. 1998. Application of kriging to estimating mean annual precipitation in a region of orographic influence. Journal of the American Water Resources Association 24(2): 329339.

8. Dios-Palomares, R. and J. A. Roldan. 2006. A strategy for testing the unit root in AR (1) model with intercept: A Monte Carlo experiment. Journal of Statistical Planning and Inference 136(8): 2685-2705. 
9. Fathizad, H., M. A. Hakimzadeh, S. R. Fallah Shamsi and S. Yaghobi. 2017. watershed-level rainfall erosivity mapping using GIS-based geostatistical modeling. Earth Sciences Research Journal 5(1): 13-22.

10. Franke, R. 1982. Smooth interpolation of scattered data by local thin plate splines. Computers \& Mathematics with Applications 8 (4): 237-281.

11. Gohari, A., S. Eslamian, A. Mirchi, J. Abedi-Koupaei, A. Massah Bavani and K. Madani. 2013. Water transfer as a solution to water shortage: a fix that can backfire. Journal of Hydrology 491(1): 23-39.

12. Golshan, M., P. Ebrahimi and A. Esmeali Ury. 2015. Choosing the best interpolation method for mapping Iran's annual temperature average. Journal of Geography and Environmental Sustainability 14(5): 57-71.

13. Kazemi, H. and Kh. Qurbani. 2015. Evaluation of different interpolation methods to estimate and mapping of precipitation variables in the agricultural lands of Agh-ghola for cultivating autumn grain. Journal of Water and Soil Conservation 22(4): 1-23.

14. Khosravi, M., M. Doostkamian, H. Mirmoosavi and A. Beig Rezaei. 2014. Classification of temperature and precipitation in Iran using geostatistical methods and cluster analysis. Urban and Regional Planning 13(4): $121-132$.

15. Kotulak, K., A. Fron, A. Krankowski, G. O. Pulido and M. Henrandez-Pajares. 2017. Sibsonian and non-Sibsonian natural neighbour interpolation of the total electron content value. Acta Geophysics 65(1): 13-28.

16. Kumari, M., A. Basistha, O. Bakimchandra and C. K. Singh. 2016. Comparison of spatial interpolation methods for mapping rainfall in Indian Himalayas of Uttarakhand region. PP. 159-168. In: Raju N. (Ed.), Geostatistical and Geospatial Approaches for the Characterization of Natural Resources in the Environment. Springer, Cham, Switzerland.

17. Lark, R. M. 2000. Estimating variograms of soil properties by the method-of-moments and maximum likelihood. Eurpian Journal of Soil Science 51: 717-728.

18. Madani, K. and M. A. Marino. 2009. System dynamics analysis for managing Iran's Zayandeh-Rud River Basin. Water Resource Management 23(11): 2163-2187.

19. Maris, F. P., K. Kitikidou, P. Angelidis and S. Potouridis. 2013. Kriging interpolation method for estimation of continuous spatial distribution of precipitation in Cyprus. British Journal of Applied Science \& Technology 3 (4): 1286-1300.

20. Merwade, V. M., D. R. Maidment and J. A. Goff. 2006. Anisotropic considerations while interpolating river channel bathymetry. Journal of Hydrology 331(3-4): 731-741.

21. Mitas, L. and H. Mitasova. 1988. General variational approach to the interpolation problem. Computers \& Mathematics with Applications 16(12): 983-992.

22. Mojarad, F. and H. Kakaei. 2015. The application of interpolation and regression methods for precipitation estimation (case study: Kermanshah province). Journal of Geographical Planning 16(5): 181-197.

23. Moral, F. J. 2010. Comparison of different geostatistical approachesto map climate variables: application to precipitation. International Journal of Climatology 30(4): 620-631.

24. Saghafian, B., H. Ramzkhah and B. ghermez cheshme. 2012. Spatial mapping of the mean annual precipitation usinggeostatistics techniques (Case study: Fars province). Journal of Water Process Engineering 4(9): 29-38.

25. Sari Saraf, B. and K. Azarm. 2016. Estimation of precipitation spatial variations in the middle Zagros with interpolation methods. Geographical Notion 15(8): 54-67.

26. Shapiro, S. S. and M. B. Wilk. 1965. An analysis of variance test for normality (complete samples). Biometrika 52 (3-4): 591-611.

27. Sibson, R. 1981. A brief description of natural neighbor interpolation. PP. 21-36. In: Barnett, V. (Ed.), Interpreting Multivariate Data. Wiley \& Sons, Chichester, New York, USA.

28. Sukumar, N., B. Moran, A. Yu Semenov and V. V. Belikov. 2001. Natural neighbour Galerkin methods. International Journal for Numerical Methods in Engineering 50(1): 1-27.

29. Ver Hoef, J. M. 1993. Universal kriging for ecological data. PP. 447-453. In: Goodchild, M. F., B. O. Parks, L. T. Steyaert (Ed.), Environmental Modelling with GIS, Oxford University Press, New York, USA.

30. Wang, W., P. H. A. J. M. Van Gelder and J. K. Vrijling. 2005. Trend and Stationary analysis for streamflow processes of rivers in Western Europe in 20th century. In: Proceeding of the IWA International Conference on Water Economics, Statistics and Finance, Rethymno, Greece.

31. Webster, R. and M. A. Oliver. 2000. Geostatistics for Environmental Scientists. ${ }^{\text {nd }}$ Edition. Wiley Press, Chichester, New York, USA.

32. Young, K. C. 1992. A three-way model for interpolating monthly precipitation values. Monthly Weather Review 120(11): 2561-2569.

33. Zareian, M. J., S. Eslamian and H. R. Safavi. 2014. A modified regionalization weighting approach for climate change impact assessment at watershed scale. Theoretical and Applied Climatology 22(3-4): 497-516. 


\title{
Accuracy Analysis of Precipitation Regionalization Methods Based on Spatial Interpolation Techniques in Zayandeh-Rud River Basin
}

\author{
M. A. Amini ${ }^{*}$, G. Torkan $^{1}$, S. S. Eslamian ${ }^{1}$, M. J. Zareian² and A. A. Besalatpour ${ }^{3}$
}

(Received: August 6-2017; Accepted: November 28-2017)

\begin{abstract}
In the present study, we used 27 precipitation average monthly data from synoptic, climatologic, rain-guage and evaporative stations located in Zayandeh-Rud river basin for the period of 1970-2014. Before interpolating, the missing data in the time series of each station was reconstructed by the normal ratio method. Also, for the data quality control, the Dickey-Fuller and Shapiro-Wilk tests were used to check the data stationarity and normality. Then, these data were interpolated by six interpolation methods including Inverse Distance Weighting, Natural Neighbor, Tension Spline, Regularized Spline, Ordinary Kriging and Universal Kriging; then each method was evaluated using the crossvalidation technique with MAE, MBE and RMSE indices. The results showed that among the spatial interpolation methods, Natural Neighbor method with MAE of 0.24 had the best performance for interpolating precipitation among all of the methods. Also, among Ordinary Kriging, Universal Kriging, Spline and Inverse Distance Weighting methods, respectively, Exponential Kriging with MAE 0.54, Quadratic Drift Kriging with MAE of 0.5, Tension Spline with the MAE of 0.54 and Inverse Distance Weighting with the power of 4 with MAE of 0.57 had the least error compared to other IDW methods.
\end{abstract}

Keywords: Dickey-Fuller test, Shapiro-Wilk test, Monthly precipitation, Zayandeh-Rud River Basin, Spatial Interpolation methods

1. Department of Water Engineering, College of Agriculture, Isfahan University of Technology, Isfahan, Iran.

2. Water Research Institute (WRI), Ministry of Energy, Tehran, Iran.

3. Inter $3 \mathrm{GmbH}$ - Institute for Resource Management, Berlin, Germany.

*: Corresponding Author, Email: aminiamin2016@gmail.com 